\title{
Effect of fetal cerebellum tissue transplantation on the spasticity and chronic pain syndrome after spinal cord injury in rats
}

\author{
Medvediev V. V. ${ }^{1}$, Senchyk Yu. Yu. ${ }^{2}$, Tatarchuk M. M. ${ }^{3}$, Draguntsova N. G. ${ }^{3}$, Dychko S. M. ${ }^{3}$, Tsymbaliuk V. I. ${ }^{3}$ \\ ${ }^{1}$ Bogomoletz National Medical University, Kyiv, Ukraine \\ ${ }^{2}$ Kyiv city clinical emergency hospital, Kyiv, Ukraine \\ ${ }^{3}$ A. P. Romodanov State Institute of Neurosurgery NAMS of Ukraine, Kyiv, Ukraine \\ e-mail:vavo2010@gmail.com
}

\section{ABSTRACT}

The syndromes of spasticity and chronic pain are diagnosed in the majority of patients in different periods of recovering from spinal injury. Current synthetic or semi-synthetic matrixes, tissue and cell transplants, which are used in the treatment of spinal cord injuries, can affect the development of the syndrome of spasticity and chronic pain.

OBJECTIVE. To examine the effect of fetal cerebellum tissue transplantation (FCTT) on the course of the spasticity and chronic pain syndrome after experimental spinal cord injury.

MATERIALS AND METHODS. Animals - albino outbred male rats (5.5 months, 300 grams, inbred line, the original strain - Wistar); main experimental groups: 1 - spinal cord injury only $(n=16), 2$ - spinal cord injury + immediate homotopical implantation of a fragment of the fetal cerebellum tissue $(n=15)$. Model of injury - left-side spinal cord hemisection at $T_{11}$ level; verification of spasticity - by Ashworth scale and electroneuromyography, severe pain syndrome - by autophagy.

RESULTS. FCTT does not affect the frequency of severe neuropathic pain syndrome, is accompanied by early (1st week) debut of spasticity signs, significantly increases the level of spasticity (1 $1^{\text {st }} 3^{\text {rd }}$ weeks), which is most likely due to glutamatergic effect of descendants of immature transplant cells - cerebellar granular neurons precursors. The maximum increase of the spasticity in the case of FCTT was observed at the $3^{\text {rd }}$ week, in the control group - within the $1^{\text {st }}$ and $4^{\text {th }}$ weeks; from the $4^{\text {th }}$ week after FCTT till the end of the experiment stabilization of spasticity rate in the range of 1.8-2.1 points was observed, which is probably due to the autoimmune motoneurons loss in the perifocal area. At the $24^{\text {th }}$ week the level of spasticity in the case of FCTT succumbed to $2.1 \pm 0.3$ points, in the control group $-2.6 \pm 0.4$ Ashworth's points $(p>0.05)$.

CONCLUSION. Immediate fetal cerebellum tissue transplantation in rats with spinal cord injury causes early pro-spastic effect, in the long term stabilizes spasticity level.

KEYWORDS: spinal cord injury; fetal cerebellum tissue transplantation; motor function recovery; posttraumatic spasticity syndrome; chronic pain syndrome

Overcoming the effects of the vertebral-spinal injury is one of the important applied and fundamental problems of modern biomedical science that has significant socio-economic importance [1]. Improving the quality of life for spinal patients, returning them to active work remains an important priority of modern restorative neurosurgery. The solution to this problem is associated with the development of biogenic and abiogenic means of motor function recovery. The technology of «exo- skeletonization» is thriving and by productivity is currently ahead of biogenic ways of motor function restoration, but has features that hinder widespread introduction. In particular, in this case it is important to have minimum of conscious motor activity of paretic limbs, to save a certain amount of downward supraspinal fibres, to maintain a certain level of pelvic organs functions, i.e. the minimum downward innervation of lumbosacral autonomic centers; to eliminate the syndromes of spasticity and chronic 
pain. Thus, achievement of significant progress in the treatment of spinal cord injury consequences is possible under conditions of complex use of two directions - neural tissue engineering and bionic prosthetics, against the elimination of spasticity and chronic pain syndromes.

Spasticity syndrome is diagnosed in $45-78 \%$ of patients in different periods of recovering from spinal injury [2,3], chronic pain - in 60-80\% $[4,5]$. All currently known synthetic or semi-synthetic matrixes, tissue and cell transplants could affect the development of spasticity [6] and chronic pain [7-15] syndromes.

The manifestation of spasticity and neuropathic pain syndrome during spinal cord injury is associated with an increased excitability of neurons and formation of pathological neuronal network at the posterior horn. [16] The main mechanism of the positive impact of biogenic means of the nervous system pathology rehabilitation is to stimulate neuroplastic process. Most growth factors, which tissue grafts or transplanted cells express, activate neuro plastic process [16]. The leader in content of immature neuroectodermal cells is cerebellum tissue at the later stages of gestation [17-22]. In this regard, it is important to study the effect of neural tissue transplantation in the course of spasticity and chronic pain syndromes at spinal cord injury. This paper deals with the impact of immediate tissue allotransplantation of fetal rat cerebellum in the area of hemisection of the spinal cord in course of these two complications of spinal cord injury.

\section{MATERIALS AND METHODS}

The research was conducted in compliance with current Bioethics regulations according European Communities Council Directives of 24 November 1986 (86/609 / EEC), the European Convention for the Protection of vertebrate animals used for experimental and scientific purposes (Strasbourg, 1986), the Law of Ukraine №3447-IV «On protection of animals from cruelty» (2006). For the study we used white mongrel male rats of the vivarium State institution «Institute of neurosurgery $n$. acad. A. P. Romodanov NAMS Ukraine», age 5.5 months, weighing about 350 grams, held under standard conditions with the usual diet.

We formed 3 experimental groups:

1) control group («Control»), animals with simulated spinal cord injury - left-sided hemisection of the spinal cord at $T_{11}(n=16,9$ of the animals involved in electroneuromyography, the maximum observation period - 26 weeks);

2) group of fetal cerebellum tissue transplantation (FCTT) animals with similar simulated injury of the spinal cord and immediate transplantation of allogenic tissue of fetal cerebellum in the affected area $(n=15,9$ of the animals involved in electroneuromyography, the maximum observation period - 26 weeks);

3 ) group of mature (3 months) intact animals $(n=7)$ for comparing the data of electroneuromyography.

Protocol of spinal cord injury modelling by left-sided cross section of the spinal cord and FCTT are described in detail in previous studies [23, 24]. After anesthesia (intraperitoneal administration of $15 \mathrm{mg} / \mathrm{kg}$ xylazine («Sedazin», Biowet, Poland) and $70 \mathrm{mg} / \mathrm{kg}$ ketamine («Calypsol», A. Gedeon Richter, Hungary) and fixing animals, we performed back access to spinal cord at $T_{11}$ and crossed its left half. Fetal cerebellar tissue was removed from rat fetuses 18 days of gestation (E18) obtained from deeply anesthetized (see above) pregnant females. One of the fragments was used to calculate the proportion of viable cells, which was $76 \pm 5 \%$. We placed a fetal cerebellum fragment size of $\sim 2 \mathrm{~mm}^{3}$ in the spinal cord wound of «FCTT» group animals. In animals of all experimental groups, the window of access to the spinal canal was covered with a fragment of subcutaneous fascia layers. Soft tissue and skin were sutured. Solution bicyllin-5 150-200 thousand U per animal (Kyivmedpreparat, Ukraine) was injected subcutaneously in the back neck area, intraperitoneally $6 \mathrm{mg} / \mathrm{kg}$ of dexamethasone (KRKA, Slovenia)

Level paretic limb spasticity was assessed by B. Ashworth scale (Table. 1) $[25,26]$ at the ankle and knee joints, fixing the highest value.
Measurement of limbs spasticity in each animal group «FCTT» was performed at $1,3,5,7,10,17,26$ weeks of observation. In connection with asynchronous testing of individual cohorts of animals from experimental groups, in this and previous studies [16, 23, 24], the raw data of each animal were led to standard timeline using interpolation method as displayed in the work. The reliability of differences between groups was assessed by comparing test results obtained at similar terms of observation.

To assess the excitability of neuronal structures below the level of the injury we used electromyographic study of $\mathrm{H}$-reflex values ( 'Hoffmann-reflex') - a phenomenon which is caused by pulsed electrical stimulation of proprioceptive la-fibers of sciatic nerve, monosynaptic excitation transfer to motoneurons and electrical excitation of gastrocnemius muscle (H-wave) [27, 28]. To electromyographic study we involved animals with SI IHL no less than 1 point Ashworth $(n=9$, group of «control»; $n=9$, group «FCTT»). Under general anaesthesia (see. Above) we performed the main access to the shaft of sciatic nerve at the upper and middle thirds of the thighs of both hind limbs. Then we installed stimulating hook-shaped platinum bipolar electrode $5 \mathrm{~mm}$ from the exit point of the pelvic nerve and generated electrical pulses of $5 \mathrm{~ms}$ by digital electroneuromyograph Neuro-MVP Micro (Neurosoft, Russia) with a frequency of $0.2 \mathrm{~Hz}$ and automatic jump-like increase in amplitude of each subsequent pulse for $1 \mathrm{~mA}$ (starting at $1 \mathrm{~mA}$ - to a significant reduction in the amplitude of the $\mathrm{H}$-wave) [32]. A concentric needle electrode recorded electrical responses in the thickness of gastrocnemius muscle. After the study, deeply anesthetized animal was euthanized using cervical dislocation. The value of recorded amplitude of $\mathrm{H}$ and $\mathrm{M}$-wave was measured by analogue method, the ratio of $\mathrm{H}$ to M-wave was calculated in percentage.

The frequency of severe pain syndrome in groups was evaluated counting the number of animals with autophagy towards paretic limbs manifestation of severe regional pain [32-34]. The animal with signs of autophagy as biting and biting off a paretic foot parts was taken out of the experiment with ethical considerations.

Statistical processing of digital data was performed using the software package STATISTICA 10.0 (StatSoft, USA). The difference between levels of paretic limb spasticity in animals of experimental groups was assessed using Mann-Whitney U-test and checked by direct data comparison for cohorts of animals at synchronous terms of observation. The difference of similar indicator at various standardized periods of observation was assessed within each group by Wilcoxon. The results of ENMG were assessed using Mann-Whitney U-test. Nonparametric Fisher's exact test was used to establish differences in the frequency of manifestation of severe pain between the experimental groups. The reliability of difference of compared values was associated with values of $p<0.05$. Calculated values were represented as $(\mathrm{M} \pm \mathrm{m})$, where $\mathrm{M}$ - mean, $\mathrm{m}$ - standard error of the mean.

Tab. 1. Ashworth scale to assess the level of paretic limb spasticity

\begin{tabular}{|c|c|}
\hline POINTS & CLINICAL EQUIVALENT \\
\hline 0 & Increase of muscle tone is missing \\
\hline 1 & $\begin{array}{l}\text { Slight increase in muscle tone, minimum tension at the } \\
\text { end of a passive movement in the joint }\end{array}$ \\
\hline 2 & $\begin{array}{l}\text { The noticeable increase in muscle tone throughout the } \\
\text { range of passive movement; passive movements are fully } \\
\text { possible }\end{array}$ \\
\hline 3 & $\begin{array}{l}\text { Significant increase in muscle tone; passive movements } \\
\text { are complicated and limited }\end{array}$ \\
\hline 4 & $\begin{array}{l}\text { Failure to exercise passive movements in the joint, } \\
\text { a condition of severe rigidity, bending or extensor } \\
\text { contracture }\end{array}$ \\
\hline
\end{tabular}


FCTT, 7 weeks

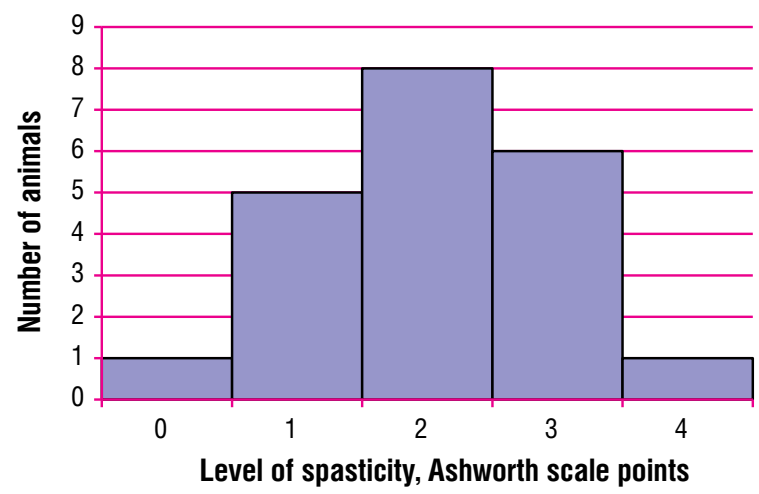

FCTT, 26 weeks

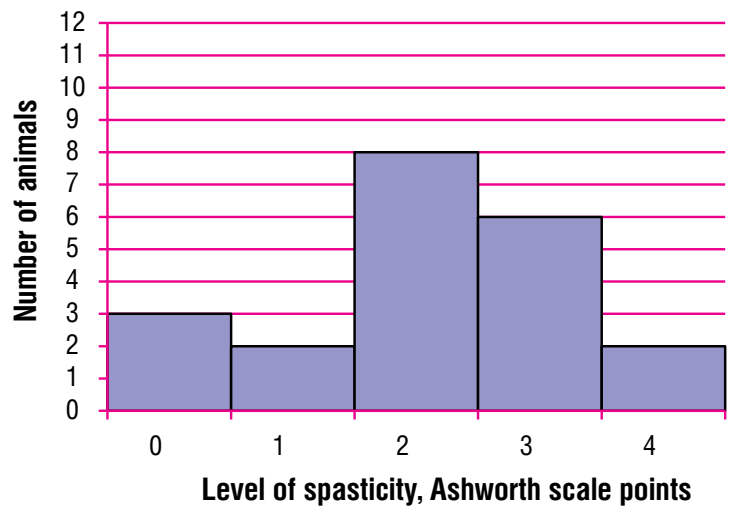

control, 7 weeks

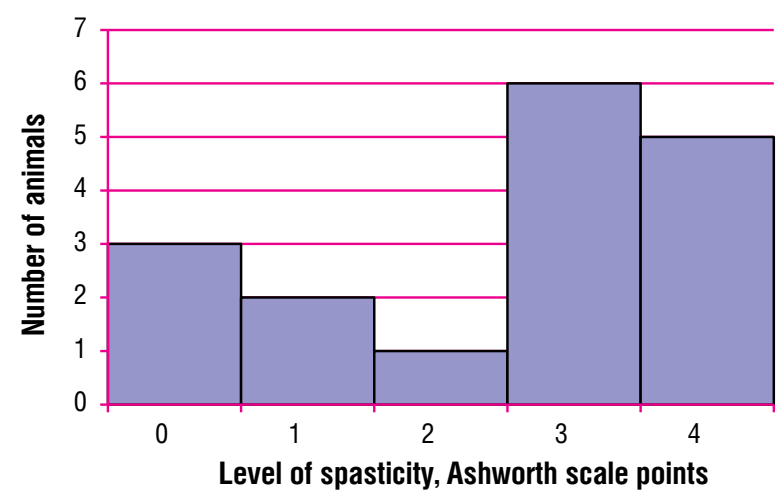

control, 26 weeks

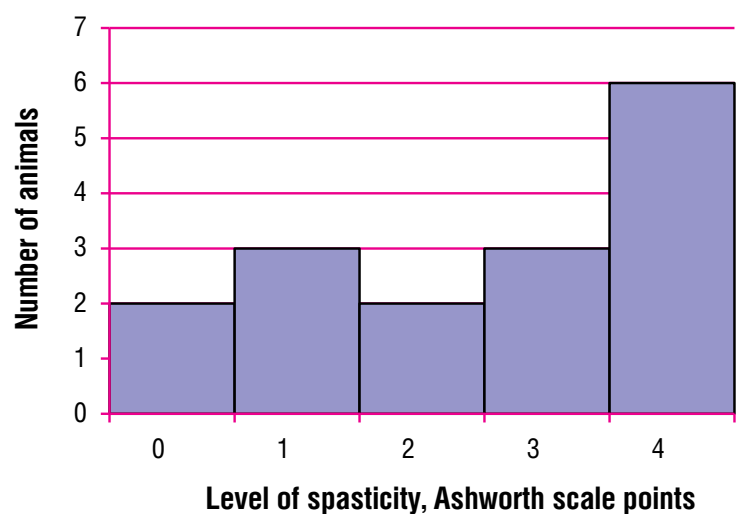

Fig. 1. Average values of paretic limb spasticity level of animals from experimental groups at the $7^{\text {th }}$ and $26^{\text {th }}$ weeks of observation.

Note: when registering a fractional value of the index, the number of animals that accounts for the next two integer values was increased by one.

\section{RESULTS AND DISCUSSION}

Group of animals after transplantation of fetal cerebellar tissue, unlike the control group throughout the observation period was characterized by a normal distribution of individual values of paretic limb spasticity (Fig. 1). At the $7^{\text {th }}$ day the average level of paretic limb spasticity in the «FCTT» amounted to $1.1 \pm 0.2$ Ashworth points, by the end of the 3rd week the figure of the «control» significantly surpassed $(p<0.05$; MannWhitney U-test; Fig. 2). Within 1-3 weeks we revealed a statistically significant increase in the level of spasticity to $1.8 \pm 0.8$ Ashworth's points $(p=0.006$; Wilcoxon); further we noted unreliable $(p>0.05$; Wilcoxon $)$ fluctuations of the indicator at around 2 Ashworth points $\left(26^{\text {th }}\right.$ week $2.1 \pm 1.1$ points). Intersection with the midrange dynamics curve of paretic limb spasticity of «control» animals accounted for 4-6th week of observation, by the end of the experiment the preference of the "control» group indicator remained unreliable (maximum -20 weeks, $p=0.204$; Mann-Whitney U-test).

Direct distribution of generated impulse along sciatic nerve to the gastrocnemius muscle leads to the formation of M-wave preceding the $\mathrm{H}$-wave [25]. The increase in ratio of amplitudes $\mathrm{H}$-wave and $\mathrm{M}$-wave (H/M-ratio) is typical for spasticity [29-31]. There is a weak positive correlation $(r=0.51)$ between the level of spasticity, measured by Ashworth scale, and $\mathrm{H} / \mathrm{M}$ ratio [25]. Comparison of average values $\mathrm{M}$ and $\mathrm{H}$ amplitude response for both hind limbs of «FCTT» animals at the 26th week of the experiment showed no significant differences (Fig. 3). The amplitude of M-response prevailed $\mathrm{H}$-response amplitude of the researched muscle of both hind limbs $(p<0.035$; Mann-Whitney U-test).
Significant $(\mathrm{p}<0.007$; Mann-Whitney U-test) difference of the value we revealed for the amplitudes of $M$ and $H$ responses, $H / M$ index of both hind limbs when compared to intact animals, excluding amplitude of $\mathrm{M}$ response of back contralateral to the place of the injury limb. The value of $\mathrm{H} / \mathrm{M}$ index for the studied paretic muscle and contralateral to limb in the «FCTT» group was $66.4 \pm 11.8 \%$ and $65.7 \pm 7.5 \%$, respectively, in the «control» $-66.8 \pm 9.8 \%$ and $66.5 \pm 15.4 \%$, in the group of intact animals $-34.1 \pm 3.2 \%$. No significant differences in investigated ENMG indicators when comparing groups of «control» and «FCTT» were found $(r \geq 0.05$; Mann-Whitney U-test).

In «control» group the phenomenon of autophagy as biting and biting off parts of paretic foot was characteristic of $18.6 \%$ animals, in the «FCTT» group we revealed in 1 animal $(6 \%)$, the difference of manifestation frequency between the two groups was unreliable $(r \geq 0$. 05; Fisher's exact test).

Rat cerebellum in the final period of ontogenesis contains a large population of precursor glutamatergic cells [17, 35-37], which, in our opinion, in the case of transplantation of immature cerebellar tissue are able to have a stimulating effect on neuronal network of adjacent areas of the spinal cord. Furthermore, neural transplant is a trigger of immune response series [38-42], while a number of inflammatory cytokines show excitatory effect on motoneurons $[43,44]$. In the short time periods (10 days), a number of inflammatory cytokines (TNFa, IL-1a, IL-6, MIP-1a) show neuron protective effect [43]. Excitatory effect of TNFa on motoneurons is considered one of the factors of glutamate-mediated formation of spasticity. In addition, tropic glutamate receptors, determining stimulant effect on neurons, are found among the series of antibodies specific to various immunogenic processes in brain tissue [45-48]. Probably, these 

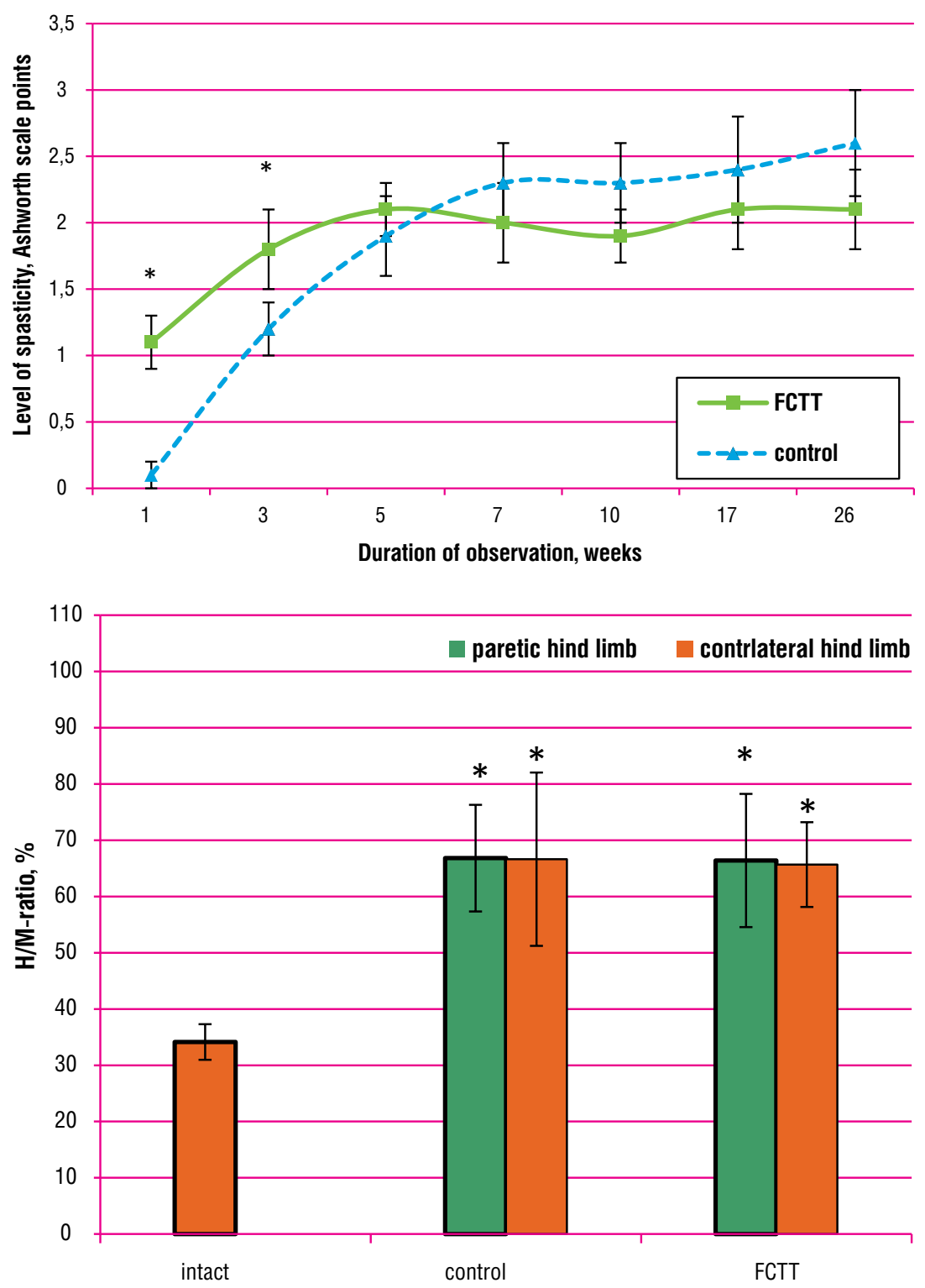

Fig. 2. The dynamic pattern of the paretic limb spasticity in animals from experimental groups. FCTT - fetal cerebellum tissue transplantation.

\section{Note: * ${ }^{*}$ significant difference} compared with the control group $(p<0.05)$.
Fig. 3. Value of $\mathrm{H} / \mathrm{M}$ for the hind limbs of experimental groups animals at the $26^{\text {th }}$ week of observation. FCTT - fetal cerebellum tissue transplantation.

Note: ${ }^{*}-p<0.05$ compared to intact animals (Mann-Whitney U-test). factors cause the early debut of paretic limb spasticity in the «FCTT.» The reason for limiting further growth of paretic limb spasticity in the «FCTT», in our opinion, is the gradual death of excessively excited motor neurons («excitotoxic death») [16, 49-54]. Glutamate, inflammatory cytokines, neurotoxic and tropic to glutamate receptors autoimmune antibodies, causing quick demonstration of spasticity syndrome at the early stages of a traumatic process, for a longer time intervals after transplantation induce elimination of excessively excited motor neurons and stabilization of spasticity dynamics in the «FCTT.»
The above pathophysiological mechanisms probably relate to excessively excited spinothalamic neurons - a substrate of chronic pain. In the case of tissue transplantation of fetal cerebellum (group «FCTT»), the frequency of this complication may not exceed the characteristic of «control».

Thus, despite the substantial content of neural progenitors in the tissue of fetal cerebellum, the use of its transplantation at spinal cord injury is possible only in the experiment, due to the potentiate effect on spasticity syndrome.

\section{CONCLUSIONS}

1. Transplantation of fetal cerebellum tissue in the area of hemisection of the rat spinal cord significantly increases the level of paretic limb spasticity for the first three weeks of observation compared with the control group and did not affect the frequency of severe neuropathic pain. 2. After transplantation of fetal cerebellar tissue, changes in the excitability of motor neurons of the spinal cord below the level of its hemisection have bilateral nature. 


\section{REFERENCES}

1. Lee BB, Cripps RA, Fitzharris $M$, et al. The global map for traumatic spinal cord injury epidemiology: update 2011, global incidence rate. Spinal Cord. 2014; $\mathbf{5 2 ( 2 )}$ 110-16.

2. Malhotra S, Pandyan AD, Day CR, et al. Spasticity, an impairment that is poorly defined and poorly measured. Clin Rehabil. 2009; 23(7): $651-58$.

3. Hwang M, Zebracki K, Chlan KM, et al. Longitudinal changes in medical complications in adults with pediatric-onset spinal cord injury. J Spinal Cord Med. 2014; 37(2): $171-78$.

4. Christensen MD, Hulsebosch C. Chronic central pain after spinal cord injury. J Neurotrauma. 1997; 14(8): 517-37.

5. Finnerup NB, Norrbrink C, Trok K, et al. Phenotypes and predictors of pain following traumatic spinal cord injury: a prospective study. J Pain. $2014 ; 15(1)$ : 40-48.

6. Wu J, Sun $T$, Ye $C$, et al. Clinical observation of fetal olfactory ensheathing glia transplantation (OEGT) in patients with complete chronic spinal cord injury. Cell Transplant. 2012; 21(1): 33-37.

7. Hofstetter CP, Holmström NAV, Lilja JA, et al. Allodynia limits the usefulness of intraspinal neural stem cell grafts; directed differentiation improves outcome. Nature Neurosci. 2005; 8(3): 346-53.

8. Macias MY, Syring MB, Pizzi MA, et al. Pain with no gain: Allodynia following neural stem cell transplantation in spinal cord injury. Exp Neurology. 2006; 201: 335-48.

9. Piltti K, Salazar D, Uchida N, et al. Safety of human neural stem cell transplantation in chronic spinal cord injury. Stem Cell Transl Med. 2013; 2: 961-974. Available: http://dx.doi.org/10.5966/sctm.2013-0064

10. Roh DH, Seo MS, Choi HS, et al. Transplantation of human umbilical cord blood or amniotic epithelial stem cells alleviates mechanical allodynia after spinal cord injury in rats. Cell Transplant. 2013; 22(9): 1577-90.

11. Luo Y, Zou Y, Yang L, et al. Transplantation of NSCs with OECs alleviates neuropathic pain associated with NGF downregulation in rats following spinal cord injury. Neurosci Lett. 2013; 549: 103-108. Available: http://dx.doi.org/10.1016/j.neulet.2013.06.005

12. Yao ZG, Sun XL, Li P, et al. Neural stem cells transplantation alleviate the hyperalgesia of spinal cord injured (SCI) associated with down-regulation of BDNF. Int J Clin Exp Med. 2015; 8(1): 404-412. Available: www.ijcem.com/ISSN:1940-5901/IJCEM0003074

13. Watanabe $S$, Uchida $K$, Nakajima $H$, et al. Early transplantation of mesenchymal stem cells after spinal cord injury relieves pain hypersensitivity through suppression of pain-related signaling cascades and reduced inflammatory cell recruitment. Stem Cells. 2015; 33(6): 1902-1914.

14. Yousefifard M, Nasirinezhad F, Manaheji HS, et al. Human bone marrow-derived and umbilical cord-derived mesenchymal stem cells for alleviating neuropathic pain in a spinal cord injury model. Stem Cell Res Ther. 2016; 7(36): 1-14.

15. Hua $R, L i P$, Wang $X$, et al. Evaluation of somatosensory evoked potential and pain rating index in a patient with spinal cord injury accepted cell therapy. Pain Physician. 2016; 19: 659-666.

16. Tsymbaliuk VI, Medvediev VV. Spinnoy mozg. Elegiya nadezhdy: monografiya [Spinal cord. Elegy of hope: a monograph]. Vinnitsa: Nova Kniga - Vinnitsa: New Book, 2010. 944 p. [in Russian]

17. Marzban H, Del Bigio MR, Alizadeh J, et al. Cellular commitment in the developing cerebellum. Front Cell Neurosci. 2015; 8: 1-26. Available: http://journal.frontiersin. org/article/10.3389/fncel.2014.00450/full

18. Kumar M, Csaba Z, Peineau S, et al. Endogenous cerebellar neurogenesis in adult mice with progressive ataxia. Ann Clin TransI Neurol. 2014; 1(12): 968-81.

19. Chang JC, Leung M, Gokozan HN, et al. Mitotic events in cerebellar granule progenitor cells that expand cerebellar surface area are critical for normal cerebellar cortical lamination in mice. J Neuropathol Exp Neurol. 2015; 74(3): 261-72.

20. Ma $M, W u W, L i Q$, et al. N-myc is a key switch regulating the proliferation cycle of postnatal cerebellar granule cell progenitors. Sci Rep. 2015; 5: 1-13. Available: https://www.ncbi.nlm.nih.gov/pmc/articles/PMC4523855/

21. Leffler SR, Legué E, Aristizábal O, et al. A mathematical model of granule cell generation during mouse cerebellum development. Bull Math Biol. 2016; 78(5): 859-78.

22. Zhu $T$, Tang $H$, Shen $Y$, et al. Transplantation of human induced cerebellar granular-like cells improves motor functions in a novel mouse model of cerebellar ataxia. Am J Transl Res. 2016; 8(2): 705-18.

23. Tsymbaliuk VI, Medvediev VV, Semenova VM, et al. Model' peretinu polovini poperechnika spinnogo mozku. I. Tehnichni, patomorfologichni ta kliniko-eksperimental'ni osoblivosti [The Model of crossing of half-transverse diameter of the spinal cord. I. Technical, pathomorphological, clinical and experimental features]. Ukr nejrohirurg zhurnal - Ukrainian Neurosurgical Journal. 2016; 2: 18-27. [In Ukrainian]

24. Medvediev VV, Senchyk YuYu, Draguntsova NG, Dychko SM, Tsymbaliuk VI. Effect of fetal cerebellar tissue transplantation on the restoration of hind limb locomotor function in rats with spinal cord injury. Cell and Organ Transplantology. 2016; 4(2):175-180. doi:10.22494/COT.V4I2.57

25. Dong HW, Wang $L H$, Zhang M, et al. Han Decreased dynorphin A (1-17) in the spinal cord of spastic rats after the compressive injury. Brain Res Bull. 2005; 67(3): 189-195.

26. Hahm SC, Yoon YW, Kim J. High-frequency transcutaneous electrical nerve stimulation alleviates spasticity after spinal contusion by inhibiting activated microglia in rats. Neurorehabil Neural Repair. 2015; 29(4): 370-381.

27. Palmieri RM, Ingersoll CD, Hoffman MA. The hoffmann reflex: methodologic considerations and applications for use in sports medicine and athletic training research. J Athl Train. 2004; 39(3): 268-277.

28. Yates C, Garrison K, Reese NB, et al. Novel mechanism for hyper-reflexia and spasticity. Prog Brain Res. 2011; 188: 167-180.

29. Tan AM, Chakrabarty S, Kimura $H$, et al. Selective corticospinal tract injury in the rat induces primary afferent fiber sprouting in the spinal cord and hyperreflexia. J Neurosci. 2012; 32(37): 12896-908.

30. Bandaru SP, Liu S, Waxman SG, et al. Dendritic spine dysgenesis contributes to hyperreflexia after spinal cord injury. J Neurophysiol. 2015; 113:1598-615.

31. Barakat MI, Elhady W, Gouda M, et al. Surgical management of intractable spasticity. Eur Spine J. 2016; 25(3): 928-935.

32. Tsymbaliuk VI, Medvediev VV, Gridina NY. Model' poperechnogo peresichennja polovini spinnogo mozku. II. Stan nervovo-m'jazovogo aparatu, sindrom poststravmatichnoï spastichnosti ta hronichnij bol'ovij sindrom [The Model of crossing of half transverse diameter of the spinal cord. II. The state of the neuromuscular system, post-traumatic spastic syndrome and chronic pain syndrome]. Ukr nejrohirurg zhurnal - Ukrainian Neurosurgical Journal. 2016; 3: 9-17. [In Ukrainian]

33. Christensen MD, Everhart AW, Pickelman JT, et al. Mechanical and thermal allodynia in chronic central pain following spinal cord injury. Pain. 1996; 68(1): 97-107.

34. Sharp KG, Dickson AR, Marchenko SA, et al. Salmon fibrin treatment of spinal cord injury promotes functional recovery and density of serotonergic innervation. Exp Neurol. 2012; 235(1): 345-56.

35. Hashimoto M, Hibi M. Development and evolution of cerebellar neural circuits. Dev Growth Differ. 2012; 54(3): 373-89.

36. Hoshino M. Neuronal subtype specification in the cerebellum and dorsal hindbrain. Dev Growth Differ. 2012; 54(3): 317-26.

37. Jankowski J, Miething A, Schilling K, et al. Cell death as a regulator of cerebellar histogenesis and compartmentation. Cerebellum. 2011; 10: 373-92. 
38. Tsymbaliuk VI, Medvediev VV, Senchik YuY. Cerebellum, abo mozochok: monografiya [Cerebellum: monograph]. Vinnitsa: Nova Kniga - Vinnitsa: New Book, 2013. 272 p. [In Ukrainian]

39. Casella GTB, Marcillo A, Bunge MB, et al. New vascular tissue rapidly replaces neural parenchyma and vessels destroyed by a contusion injury to the rat spinal cord. Exp Neurol. 2002; 173(1): 63-76.

40. Garcia E, Aguilar-Cevallos J, Silva-Garcia R, et al. Cytokine and growth factor activation in vivo and in vitro after spinal cord injury. Mediators Inflamm. 2016; 2016: 1-21. Available: https://www.hindawi.com/journals/mi/2016/9476020

41. Kjell J, Olson L. Rat models of spinal cord injury: from pathology to potential therapies. Dis Model Mech. 2016; $\mathbf{9 ( 1 0 ) : ~} 1125-137$.

42. Le Blon D, Hoornaert C, Detrez JR, et al. Immune remodelling of stromal cell grafts in the central nervous system: therapeutic inflammation or (harmless) side-effect? J Tissue Eng Regen Med. 2016; doi: 10.1002/term.2188. [Epub ahead of print].

43. Pajer K, Feichtinger G, Márton G, et al. Cytokine signaling by grafted neuroectodermal stem cells rescues motoneurons destined to die. Exp Neurol. 2014; 261:180189.

44. Centonze D. Advances in the management of multiple sclerosis spasticity: multiple sclerosis spasticity nervous pathways. Eur Neurol. $2014 ;$ 72(I): 6-8.

45. Kapadia M, Sakic B. Autoimmune and inflammatory mechanisms of CNS damage. Prog Neurobiol. 2011; 95(3): $301-33$.

46. Levite M. Glutamate receptor antibodies in neurological diseases. J Neural Transm. 2014; 121(8): 1029-75.

47. Bakpa OD, Reuber M, Irani SR. Antibody associated epilepsies: clinical features, evidence for immunotherapies and future research questions. Seizure. 2016 ; 41: 26-41.

48. Dalmau J, Geis C, Graus F. Autoantibodies to synaptic receptors and neuronal cell surface proteins in autoimmune diseases of the central nervous system. Physiol Rev. 2017; 97(2): 839-87.

49. D'Amico JM, Condliffe EG, Martins KJB, et al. Recovery of neuronal and network excitability after spinal cord injury and implications for spasticity. Front Int Neurosci. 2014; 8: 1-24. Available: http://journal.frontiersin.org/article/10.3389/fnint.2014.00036/full

50. Crowe MJ, Bresnahan JC, Shuman SL, et al. Apoptosis and delayed degeneration after spinal cord injury in rats and monkeys. Nat Med. $1997 ; \mathbf{3 ( 1 ) : ~ 7 3 - 7 6 . ~}$

51. Liu XZ, Xu XM, Hu R, et al. Neuronal and glial apoptosis after traumatic spinal cord injury. J Neurosci. 1997; 17: 5395-406.

52. Kim P, Haisa T, Kawamoto T, et al. Delayed myelopathy induced by chronic compression in the rat spinal cord. Ann Neurol. 2004; 55(4): 503-11.

53. Moghaddam A, Child C, Bruckner T, et al. Posttraumatic inflammation as a key to neuroregeneration after traumatic spinal cord injury. Int J Mol Sci. 2015; 16(4): 7900-916.

54. Shabbir A, Bianchetti E, Cargonja R, et al. Role of HSP70 in motoneuron survival after excitotoxic stress in a rat spinal cord injury model in vitro. Eur J Neurosci. 2015; 42(12): 3054-65.

55. Pajer K, Feichtinger G, Márton G, et al. Cytokine signaling by grafted neuroectodermal stem cells rescues motoneurons destined to die. Exp Neurol. $2014 ; \mathbf{2 6 1 :} 180-89$.

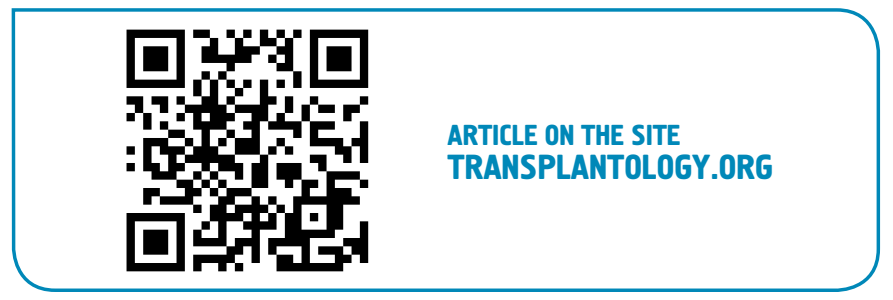

The authors indicate no potential conflicts of interest.

Received: July 21, 2016

Accepted: April 11, 2017 